\title{
"A Brief Overview of Media Perception of the Military and their Antagonistic Relationship"
}

\author{
${ }^{1}$ Haruni Ramadhani kondo, ${ }^{2}$ Dr.Dewashish Verma \\ ${ }^{1}$ Research Scholar, Journalism \& Mass Comm deptt., Monad University, Hapur \\ ${ }^{2}$ HOD- Journalism \& Mass Comm, Monad University, Hapur
}

\begin{abstract}
This research paper is based on the media perception of the military during war situations. Media and military both are interrelated to each other but they never had an easy relationship. During the wars this relationship will be the critical issue for every country. The author of this research paper have the knowledge and experience of being both a journalist and a public relations officer in the Tanzania People's Defense Forces $(T P D F)$ for more than twenty years. He lead a group of civilian and military reporters, broadcasters and filmmakers during the Tanzania/Uganda war in 1978. This research paper will focus on certain factors which contribute to the mutually antagonistic relationship between military and media.
\end{abstract}

Keyword: journalism, military, perception, war, media etc.

\section{INTRODUCTION}

The military is the group or groups of people that are given power to defend something (mostly a country). They are armed, so they are called the armed forces. A military, generally consists of an Army, Navy, Air Force, and in certain countries the Marines and Coast Guard, and also known as the Armed Forces, are forces authorized to use lethal and / or deadly force, and weapons, to support the interests of the state and some or all of its citizens. The task of the military is usually defined as defense of the state, and its citizens, and the prosecution of war against another state. The military may also have additional sanctioned and non-sanctioned functions within a society, including, the promotion of a political agenda, protecting corporate economic interests, internal population control, construction, emergency services, social ceremonies, and guarding important areas. The military may also function as a discrete subculture within a larger civil society, through the development of separate infrastructures, which may include housing, schools, utilities, logistics, health and medical, law, food production, finance and banking. Media can be expressed ad communication channels through which news, entertainment, education, data, or promotional messages are disseminated. Media includes every broadcasting and narrowcasting medium such as newspapers, magazines, TV, radio, billboards, direct mail, telephone, fax, and internet. Media is the plural of medium and can take a plural or singular verb, depending on the sense intended. From the time of the Crimean War to that of the Gulf Conflict it is the contention of this article that the relationship between these two professions has been one of almost unabated suspicion and hostility. This research will outline certain factors which contribute to this mutually antagonistic relationship. There are certain parameters are there which are helpful to analyze and discuss how the military perceive war correspondents when working with them during war time. The perceptual experience plays an important role in this research article.

\section{THE MYTH OF MiLITARY MIGHT}

In the spring of 1967 American General William C. Westmoreland asked the Johnson Administration for an additional two and one-third divisions - 100,000 men - to fight the Vietcong. This he believed, was "the minimum essential force" required to contain the enemy and to maintain the "tactical initiative". ${ }^{1}$ The General further demanded four and two-thirds divisions - an additional 201,250 men to boost the strength of the American forces in Vietnam to $671,000 .{ }^{2}$ Westmoreland claimed that these reinforcements would enable him to destroy or neutralize the enemy quickly and deny them the long established "safe havens" in South Vietnam. His request was strongly supported by the US Joint Chiefs of Staff. However even prior to Westmoreland's demands, the U.S. had already deployed a 
massive 500,000 troops, dropped 1.2 million tons of bombs annually in both South and North Vietnam, undertaken 400,000 sorties per year - all at a cost of 10 billion dollars annually. ${ }^{3}$ Despite this input, the U.S. still failed to attain its objectives, indeed, the prognostications of success were minimal. President Johnson, becoming increasingly pessimistic about the war, and visibly reluctant to pursue it, questioned the General: "When we add divisions, can't the enemy add divisions? If so, where does it all end?" This view was in line with the argument advanced by the former U.S. Initially, U.S involvement in Vietnam was characterized by American confidence that hostilities would be of short duration and at a minimal cost. They could not have been more wrong. They fought for a decade with heavy loss of life and property and still were incapable of winning. This testifies to the fact that the concept of military might can prove a myth, and this was soon recognized by the military correspondents of the period. Realizing that America could not win the war, U.S. troops resorted to wanton destruction of property and the killing of innocent civilians. Cases such as the Marines setting fire to the thatched huts of the village of Cam $\mathrm{Ne}$ with Zippo lighters were publicized by correspondents. This added to the hostility which already prevailed between the two professions during this period. The Dunkirk operation serves as another example. During the Second World War the British suffered an unprecedented defeat at Dunkirk when they attempted to evacuate their beleaguered forces from the Germans who were determined to encircle and crush them. It became clear that the British had suffered heavily in this operation, but one would never have guessed so from the press coverage at home.

\section{SECRECY AND ITS RELATIONSHIP WITH COOPERATION}

The military authorities did not wish the sad state of their operations to be reported. Failures, blunders and incompetence were buried under the banner of secrecy. Under the pretext of national security the military maintained public support by keeping its actions 'under wraps'. During the Falklands War (1982), the British Ministry of Defense declared: "The essence of successful warfare is secrecy: the essence of successful journalism is publicity. ${ }^{6}$ This testifies to the clash of interests between these two professions, both in ethics and conduct of operations. But one could ask: what is the yardstick of 'secrecy' and how does such a concept relate to the right of the people to information on a war which is fought in their name and who pay the cost of it - sometimes with their lives?. Such questions are hard to resolve because military authorities do not readily cooperate with any establishment which they regard as their enemy, for example, the media. This confirms the uncompromising attitude of military commanders when handling operations information, even during peace time. Secrecy is frequently employed as a defensive mechanism, sometimes without any logical or legitimate reasons.

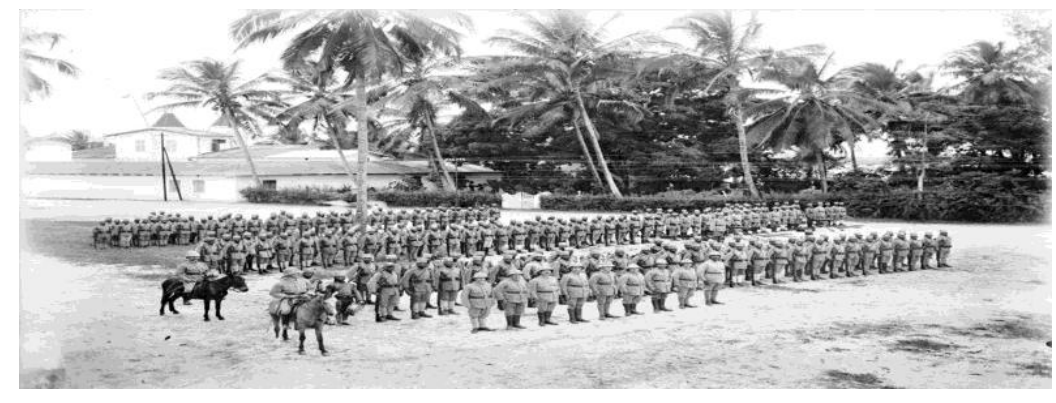

(Military in War)

\section{The Tendency to Reconstruct Reality}

Sometimes military authorities attempt to reconstruct a situation in a way contrary to the reality of the case, with the purpose of concealing the facts. After the episode during the Crimean War when Lord Raglan suffered a humiliating defeat when he ordered Lord Cardigan to advance, the former dispatched home a terse communique which was contrary to the truth of the situation. It was Russell and his compatriot correspondents who first awakened the British public by truthfully reporting the situation at the front and detailing the hardships of those thousands of combatants who were forced to suffer the negligence and incompetence of their commanders. Such reportage created an immense public impact and the government was forced to rectify the situation at the front by changing the field commanders and providing improved medical services. The American Civil War can be cited as another example. The US Secretary of War, Edwin M. Stanton doctored casualty figures to hide the truth and reconstruct the reality of the situation to save the army's credibility in the eyes of the public. He first attempted to conceal and account of General Ulysses S. Grant's failure at Petersburg by reducing the losses to about one third of their actual number. During the Second World War the 
British Air Ministry deliberately exaggerated the number of enemy planes shot down in the Battle of Britain by one third. And in what in North Africa was known as the 'Crusader' tank battle, the British claimed to have destroyed more tanks than Field-Marshall Rommel actually possessed. Defending such practices by the military in war time, former British Prime Minister Winston Churchill, in conversation with Joseph Stalin in Tehran in 1943, made the famous comment: "truth is so precious that she should always be attended by a bodyguard of lies." ${ }^{8}$ This is the rationale behind how the government has worked hand in hand with the military to deceive the public by painting a false picture of events to gain popular support.

\section{Censorship as a Means of Control and Manipulation}

Although censorship has become a normal practice in times of war, in most cases its application has proved dubious; many questions being left unanswered. In his article "Something more important than truth: ethical issues in war reporting", Kevin Williams argues "There are many obstacles to the truth being told in wartime, although it should be stressed that these also apply in peacetime but are less apparent. War should not be seen as a special case of how the media works. War highlights and intensifies many of the things that happen in peacetime. To strengthen his argument he cites Robert Harris from his work on the Falklands War: 'It briefly illuminated aspects of British society usually hidden from view. It exposed habitual abuses by the armed forces, Government, Whitehall and the media; it did not create them.' Censorship is one such abuse."Experience has shown that censorship is sometimes used by military authorities to hide the truth or to veil incompetence and failure, and on the pretext of protecting operational security. Thus such dubious practices of control and manipulation are legitimized, and the truth is victim.

Douglas Wilkie, representing a group of Australian and British newspapers including the Evening Standard of London and the Herald of Melbourne, made a two thousand mile tour of the India-Burma war theatre in 1943. Wilkie wrote twelve articles concerning the state of the campaign and dispatched them to Delhi to be censored and then cabled to his newspapers. To his dismay, Wilkie found that the censor had completely cut three of his articles and had ' trimmed' the others so drastically that they were worthless. Wilkie bitterly complained: "My final picture of one of the world's main battlefronts . .. was in large part frivolous references to elephants and tribesmen I had interpolated in more important material."'He later wrote to the Director of Army Public Relations:"If war correspondents are to be allowed to write only what the Army' wants, then it would be easier if you confined your publicity to official handouts ... It is my concern in every sense that my professional reputation should be endangered because of my editor's compulsory ignorance of your [censorship] policy . . . My articles as dispatched are not a fair index of my industry, views, or conception of the functions of a war correspondent."Wilkie delivered this letter, and in protest packed up and went home. In Japan during the Second World War the situation with regard to censorship exhibited another face. A Board of Information (a Japanese version of the OW1) ${ }^{10}$, a Patriotic Critics' Association and a Patriotic Commentators' Association were set up to control and manipulate information flow to suit military objectives.

The Domei News Agency, Radio Tokyo, and all newspapers were reorganised as "public utilities", and given a "mission". To make matters worse, a Board of Censorship, with representatives of the army, navy, Home Office and Ministry of Transport, were given a mandate to oversee all matters pertaining to censorship in Japan while service sensors were authorised to control war correspondents in the war theatres. Such methods were widely used throughout the war. All sides the allies and their adversaries Germany, Japan and Italy used censorship to control and manipulate the flow of information to suit their interests.

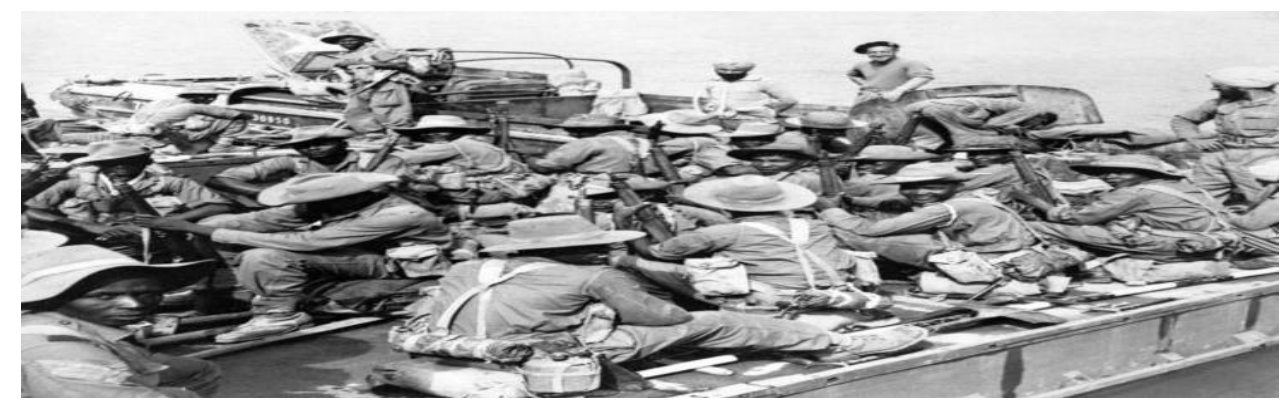

(War Situation) 


\section{Military/War Correspondents' Amnesia in Relation to Past Conflicts}

Commenting on a First World War incident which bears a similarity to that which befell Lord Raglan during the Crimea conflict, Field Marshall Montgomery, who was serving as a Platoon Commander at the time, stated in his Memoirs:"We crossed over to France as part of the 4th Division. We missed the Battle of Mons by a few days, and moved forward by march route up towards Le Cateau. On the early morning of 26th August 1914, the 10th Brigade to which my battalion belonged was bivouacked in the cornfields near the village of Haucourt after a long night march. One battalion was forward on a hill, covering the remainder of the brigade in the valley behind; we could seen the soldiers having breakfast, their rifles being piled. That battalion was suddenly surprised by the Germans and fire opened on it at short range; it withdrew rapidly down the hill towards us, in great disorder". Uponrealizing that the aforementioned battalion was in utter disorder, one of the rear battalion commanders issued an order for a counterattack without making a thorough investigation. The history of global conflict suggest that either both sides deliberately ignore the lessons to be learnt from the past, or suffer amnesia in relation to experiences which could have been usefully adapted to improve their relations with the media during war and conflict in general. However, since the Crimean War the relationship between the two has been characterised by suspicion, hatred and unease. There has been little change in the relationship between these two camps. Both are rigid in defending and adhering to their ethics and interests. Lack of flexibility on both sides continues to be a stumbling block. In 1982, ten years after the Americans were defeated in Vietnam, the British went to war with the Argentinians over the Falkland Islands. The relationship between the military and the media had by no means improved since the previous conflict. During the Gulf War, the US military authorities not only erected a physical barrier beyond which non-Anglo-American correspondents could not penetrate, but treated them with contempt and suspicion throughout the war. This, as previously stated, prompted a response from the three hundred non-pool correspondents who wrote a protest letter to King Fahd and American military authorities which had no effect. It later became clear why the allies employed such a policy. Their motives were to manoeuvre pro-western correspondents into presenting the conflict as a war without death. As Philip Knightley argues: "the war marked an alarming development in the history of censorship". There was an additional aim: "to alter public perception of the nature of war itself, particularly the fact that civilians die in war." ${ }^{12}$

\section{REFERENCES}

[1] Avirgan, Tony and Martha, Honey: The Tanzania/Uganda War. TPH, 1979.

[2] Belsey, Andrew and Chadwick, Ruth: Ethical Issues in Journalism and the Media, Routledge, 1992.

[3] Bramson, Leonand Goethals, George W. : War. Basic Books, 1968.

[4] Charlton, Michael and Moncriff, Anthony: Many Reasons Why, London, 1978.

[5] Chomsky, Noam: Manufacturing the consert, London, 1978.

[6] Furneaux, Rupert: News of War. Max Paris; London

[7] Grinter, Lawlence E. and Dunn, Peter M. : The American War in Vietnam. London, 1978.

[8] Hallin, Daniel C. The Uncensored War. Oxford University Press, 1986.

[9] Herman, Edward S. and Chomsky, Noam, Manufacturing Consent. Pantheion Books, 1988.

[10] Harris, Robert: GOTCHA, The Media, The Government and The Falklands Crisis. Faber, 1983.

[11] Herr, Michael: Dispatches. Pan Publications, 1968. Hooper, Alan: The Military and the Media. Avebury, 1982. Karnow, Stanley: Vietnam: A History. Penguin Books, 1983.

[12] Keesing's Contemporary Archives, Keesings Publications Ltd., London, VolNos XVIII, 1971-72; XXII, 1976; XXV, 1979.

[13] www.wikipedia .com 